\title{
Proliferation, migration and invasion of triple negative breast cancer cells are suppressed by berbamine via the PI3K/Akt/MDM2/p53 and PI3K/Akt/mTOR signaling pathways
}

\author{
LILI LIU $^{1 *}$, JIADONG YAN ${ }^{1 *}$, YING CAO $^{1}$, YAN YAN $^{1}$, XIANG SHEN $^{2}$, \\ BINBIN YU $^{1}$, LI TAO $^{1}$ and SHUSHENG WANG ${ }^{2}$ \\ Departments of ${ }^{1}$ Pharmacy and ${ }^{2}$ General Surgery, The Affiliated Zhangjiagang Hospital of Soochow University, \\ Suzhou, Jiangsu 215600, P.R. China
}

Received February 17, 2020; Accepted October 27, 2020

DOI: $10.3892 / \mathrm{ol} .2020 .12331$

\begin{abstract}
Breast cancer is the second most common cause of cancer-associated mortality among women worldwide, and triple negative breast cancer (TNBC) is the most aggressive subtype of breast cancer. Berbamine (BBM) is a traditional Chinese medicine used for the treatment of leukopenia without any obvious side effects. Recent reports found that BBM has anti-cancer effects. The present study aimed to investigate the effects of BBM on TNBC cell lines and the underlying molecular mechanism. MDA-MB-231 cells and MCF-7 cells, two TNBC cell lines, were treated with various concentrations of BBM. A series of bioassays including MTT, colony formation, EdU staining, apoptosis, trypan blue dye, wound healing, transwell, ELISA and western blotting assays were performed. The results showed that BBM significantly inhibited cell proliferation of MDA-MB-231 cells $\left(\mathrm{P}<0.05 ; \mathrm{IC}_{50}=22.72 \mu \mathrm{M}\right)$ and MCF-7 cells $\left(\mathrm{P}<0.05 ; \mathrm{IC}_{50}=20.92 \mu \mathrm{M}\right)$. BBM $(20 \mu \mathrm{M})$ decreased the apoptosis ratio (percentage of absorbance compared with the control group) by $28.4 \pm 3.3 \%(\mathrm{P}<0.05)$ in MDA-MB-231 cells, and $62.4 \pm 24.6 \%(\mathrm{P}<0.05)$ in MCF-7 cells. In addition, BBM inhibited cell migration and invasion of TNBC cells. Furthermore, the expression levels of PI3K, phosphorylated-Akt/Akt, COX-2, LOX, MDM2 and mTOR were downregulated by BBM, and the expression of p53 was upregulated by BBM. These results indicated that BBM may suppress the development of TNBC via regulation of
\end{abstract}

Correspondence to: Professor Shusheng Wang, Department of General Surgery, The Affiliated Zhangjiagang Hospital of Soochow University, 68 Jiyang Road, Zhangjiagang, Suzhou, Jiangsu 215600, P.R. China

E-mail: wsszjg123@163.com

*Contributed equally

Key words: berbamine, triple-negative breast cancer, anti-cancer effects, apoptosis, MDM2, mTOR the PI3K/Akt/MDM2/p53 and PI3K/Akt/mTOR signal pathways. Therefore, BBM might be used as a drug candidate for the treatment of TNBC in the future.

\section{Introduction}

Breast cancer is the second most common cause of cancer-associated mortality in women globally, accounting for $16 \%$ of cancer-associated mortalities in adult women annually (1-3). Triple negative breast cancer (TNBC) is the most aggressive subtype of breast cancer and is characterized by a lack of hormone receptors, such as estrogen receptor (ER), progesterone receptor (PR) and human epidermal growth factor receptor 2 (HER2) (4). Given that this subtype cannot be treated with molecular targeted therapies towards these receptors/hormones, the treatment of TNBC is challenging and these patients typically exhibit a poor prognosis $(5,6)$. Currently, surgery, chemotherapy and radiation therapy are the standard methods of treatment for breast cancer; however, the 5 -year survival rate for patients with breast cancer of advanced stages remains low from 2010-2015 (7). Additionally, treatments for patients with advanced breast cancer result in undesirable therapeutic effects, since relapse often occurs after treatment (1). Therefore, the development of effective anti-cancer drugs with minimum side effects is critical.

Traditional Chinese Medicine has provided multiple medicinal resources and materials for the treatment of a variety of cancers. Berbamine (BBM) is derived from Berberis amunrensis. As a small molecule of natural origin, BBM has been widely used to treat leukopenia caused by chemotherapy and/or radiotherapy, without any obvious side effects (8). Previous studies reported that BBM possesses biological activities including anti-oxidation, anti-inflammation and protective effects against ischemia/reperfusion injury (9-11). In addition, BBM exhibits anti-tumor activity and inhibits the proliferation of breast cancer cell lines $(8,12)$. Although previous studies have demonstrated that BBM downregulates the protein levels of $\mathrm{Bax}$ and $\mathrm{Bcl}-2$ (12), the molecular mechanism underlying its anti-tumor function is still unclear. In addition, few studies have explored the effects and mechanism of BBM in breast cancer. 
Hyperactivation of the phosphatidylinositol 3 kinase/protein kinase B (PI3K/Akt) signaling pathway is associated with tumor growth, maintenance and chemotherapy resistance in several types of cancer, such as breast cancer, endometrial cancer and liver cancer (13-21). Dysregulation of signaling via the PI3K/Akt signaling pathway is one of the most frequent oncogenic aberrations associated with TNBC (22). Pierobon et al (21) reported that breast cancer with liver metastasis may be associated with increased incidence of PIK3CA mutations and activation of the PI3K/Akt/mTOR signaling pathway. These studies suggest that the mechanism underlying the effect of BBM treatment on tumors may involve the PI3K/Akt pathway. Therefore, it was hypothesized that BBM may inhibit the proliferation, invasion and metastasis of TNBC cells via the PI3K/Akt signaling pathway. Murine double minute 2 (MDM2) and mTOR were the downstream targets of Akt $(4,23), \mathrm{MDM} 2$ is a master regulator of the p53 tumor suppressor (24). Li et al (10) reported that HBXIP promotes human breast cancer growth by activating phosphorylated (p)-Akt, which in turn phosphorylates MDM2, thus enhancing the interaction between MDM2 and p53 and resulting in p53 degradation. Rinaldi et al (25) found that the mTOR pathway is related to tumor growth. Therefore, MDM2 and mTOR may serve an important role in the anti-breast cancer effects of BBM. Lysyl oxidase (LOX) and cyclooxygenase (COX)-2 are also downstream targets of the PI3K/Akt pathway $(26,27)$. Lox is overexpressed in patients with TNBC and is closely associated with tumor metastasis (28). Moreover, the expression of LOX is enhanced by the activation of PI3K (26). COX-2 is also overexpressd in patients with TNBC (29) and COX-2 promotes migration in osteosarcoma MG-63 cells via the PI3K/Akt signal pathway (27). Previous studies have demonstrated that BBM may inhibit the proliferation and metastasis of tumor cells by regulating the expression levels of several proteins, including p-Akt (30-33). However, to the best of our knowledge, there are have not been previous studies which indicate that BBM inhibits breast cancer by inhibiting the expression of PI3K, and there are no studies investigating the association between the downstream targets of Akt mentioned above (including MDM2, mTOR, LOX, and COX-2) and BBM. The present study will investigate the effects of BBM on TNBC cell proliferation, invasion and migration and will explore its underlying mechanisms. The current study will examine whether BBM inhibits the proliferation, migration and invasion of TNBC cells via regulating the PI3K/Akt pathway and downstream targets such as MDM2, p53, mTOR, COX-2 and LOX.

\section{Materials and methods}

Drugs and reagents. BBM (purity $\geq 98 \%$ ) was purchased from Shanghai Macklin Biochemical Technology Co., Ltd. and was dissolved in dimethyl sulfoxide (DMSO) at a concentration of $100 \mathrm{mM}$ as a stock solution and diluted into indicated concentrations using DMEM medium (Gibco; Thermo Fisher Scientific, Inc.), as previously described $(30,31)$. The final DMSO concentration was $<0.1 \%$ in all experiments. Fetal bovine serum (FBS) and Dulbecco's modified Eagle's Medium (DMEM) were purchased from Gibco; Thermo Fisher Scientific, Inc. Matrigel was purchased from BD Biosciences. 3-(4,5-dimethylthiazol-2-yl)-2,5-diphenyl tetrazolium bromide (MTT) and Cell Death Detection ELISA kits were purchased from Sigma-Aldrich; Merck KGaA. Primary antibodies against PI3K, MDM2, Akt, phosphorylated (p)-Akt, p53 and GAPDH, and the ELISA kit for mTOR, were purchased from Abcam. LOX, COX-2 and $\beta$-actin antibodies were purchased from Santa Cruz Biotechnology, Inc. Trypan Blue assay kits and all other reagents for western blotting were purchased from Beyotime Institute of Biotechnology.

Cell culture. The human TNBC cell lines MDA-MB-231 and MCF-7 were purchased from the Cell Bank of the Chinese Academy of Sciences. The cells were cultured in DMEM medium containing $10 \% \mathrm{FBS}$ and $1 \%$ penicillin-streptomycin and stored in a humidified incubator at $37^{\circ} \mathrm{C}$ with $5 \% \mathrm{CO}_{2}$.

MTT assay. MDA-MB-231 cells and MCF-7 cells were seeded into a 96 -well plate $\left(5 \times 10^{4}\right.$ cells/well) and treated with vehicle (DMEM medium with $0.08 \%$ DMSO) or different concentrations of $\operatorname{BBM}(1.25,2.5,5,10,20,40$, and $80 \mu \mathrm{M})$ for $24 \mathrm{~h}$ at $37^{\circ} \mathrm{C}$. MTT solution $(5 \mathrm{mg} / \mathrm{ml})$ was added to each well and the plate was incubated for another $4 \mathrm{~h}$ at $37^{\circ} \mathrm{C}$. Next, the supernatant was removed and DMSO solution was added. The absorbance was read by a Multi-Well Micro-Plate Reader (Bio-Rad Laboratories, Inc.) at $560 \mathrm{~nm}$. Cell viability was expressed as a percentage of the vehicle $(\mathrm{Ctrl})$ group.

Colony formation assay. The colony formation assay was performed as previously described (29). MDA-MB-231 cells and MCF-7 cells were cultured in a 6 -well plate $\left(1 \times 10^{3}\right.$ cells/well $)$ and treated with vehicle or different concentrations of BBM $(10,20$ and $40 \mu \mathrm{M})$ for $24 \mathrm{~h}$ at $37^{\circ} \mathrm{C}$. The medium was replaced by a drug-free, complete DMEM (with $10 \%$ FBS). The medium was changed every 3 days for MAD-MB-231 cells and every 2 days for MCF-7 cells. After 7 days, the cells were fixed with $4 \%$ paraformaldehyde for $30 \mathrm{~min}$ at $25^{\circ} \mathrm{C}$ and stained with crystal violet solution $(0.05 \% \mathrm{w} / \mathrm{v})$ for $20 \mathrm{~min}$ at $25^{\circ} \mathrm{C}$. The number of clones $>10$ cells was counted under a light microscope (Leica DMI 4000; magnification, x100).

5-Ethynyl-2'-deoxyuridine (EdU) staining assay. EdU staining assay was performed using the EdU Apollo-567 in vitro kit (Guangzhou RiboBio Co., Ltd; cat. no. C10310-1). Briefly, MDA-MB-231 cells and MCF-7 cells were seeded into 96-well plates $\left(1 \times 10^{4}\right.$ cells/well $)$ and cultured overnight at $37^{\circ} \mathrm{C}$. EdU $(10 \mu \mathrm{M})$ was added into each well and incubated for $2 \mathrm{~h}$ at $37^{\circ} \mathrm{C}$. After the cells were fixed with $4 \%$ polyoxymethylene at $25^{\circ} \mathrm{C}$ for $30 \mathrm{~min}$ and decolorized with glycine $(2 \mathrm{mg} / \mathrm{ml})$ at $25^{\circ} \mathrm{C}$ for $5 \mathrm{~min}$, the cell nuclei were stained with Hoechst 33342 at $25^{\circ} \mathrm{C}$ for $30 \mathrm{~min}$. The fluorescence of cells was observed using an inverted fluorescence microscope (magnifiation, x100; Leica Microsystems $\mathrm{GmbH}$ ). The EdU ratio was calculated as follows: Number of EdU-positive cells/number of Hoechst 33342-positive cells x100\%.

Trypan Blue Dye assay. MDA-MB-231 cells (1x10 5 cells/well) were seeded into 6 -well plates in the presence or absence of different concentrations of $\operatorname{BBM}(10,20$ and $40 \mu \mathrm{M})$ and cultured at $37^{\circ} \mathrm{C}$ for $48 \mathrm{~h}$. The cells were collected and re-suspended using $0.4 \%$ Trypan blue at $25^{\circ} \mathrm{C}$. Then the cells 
A
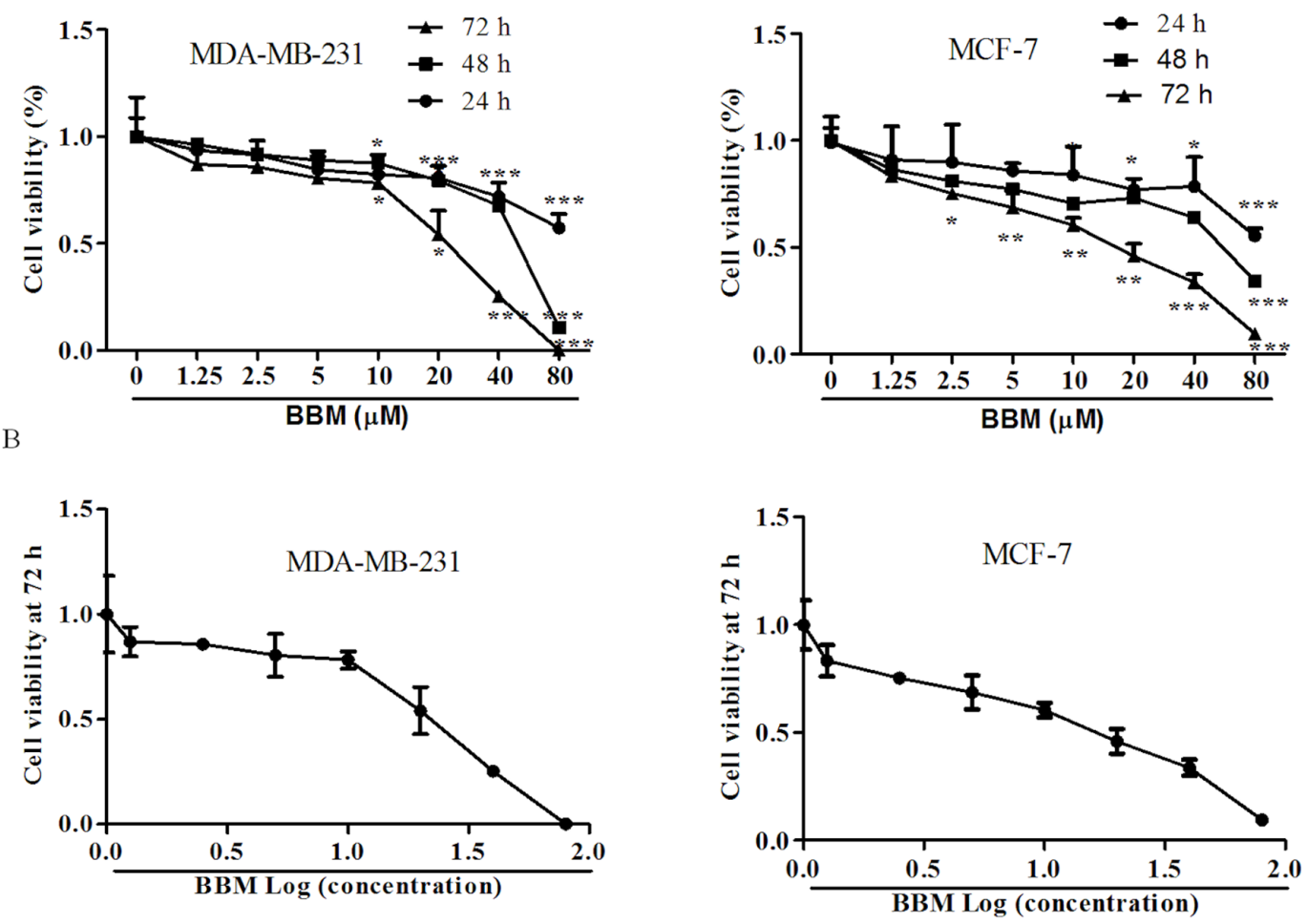

Figure 1. BBM is cytotoxic to triple negative breast cancer cells. The cells were treated with applied concentrations $(1.25,2.5,5,10,20,40$ or $80 \mu \mathrm{M})$ of $\mathrm{BBM}$, cell viability was tested using MTT assay. (A) Effects of different concentrations of BBM on cell proliferation at different times. (B) The effect of BBM on cell proliferation after treatment for $72 \mathrm{~h}$. The Ctrl group was the cells treated with solvent (medium containing DMSO, DMSO $<0.8 \%$ ). Data are presented as the mean \pm standard deviation $(\mathrm{n}=3) .{ }^{*} \mathrm{P}<0.05,{ }^{* *} \mathrm{P}<0.01,{ }^{* * *} \mathrm{P}<0.001$ vs. Ctrl group. BBM, Berbamine; Ctrl, control.

visualized under a light microscope (Leica DMI 4000; magnification, $\mathrm{x} 100)$.

Apoptosis assay. Cell apoptosis was detected using a photometric enzyme immunoassay (Cell Death Detection ELISA kit, cat. no. 11544675001; Sigma-Aldrich Merck KGaA), as previously described (30). This is based on the quantitative sandwich immunoassay employing antibodies against histone and DNA. MDA-MB-231 cells and MCF-7 cells ( $1 \times 10^{5}$ cells/well) were seeded into a 6 -well plate in the presence or absence of different concentrations of BBM $(10,20$ and $40 \mu \mathrm{M})$ and cultured for $24 \mathrm{~h}$ at $37^{\circ} \mathrm{C}$. The cells were washed with PBS and then lysed in RIPA lysis buffer (containing $1 \mathrm{mM}$ PMSF). The supernatant was collected via centrifugation at 12,000 $\mathrm{x} g$ for $15 \mathrm{~min}$ at $4^{\circ} \mathrm{C}$. and used for testing. The mono- and oligonucleosomal fragmented DNA was measured according to the instructions of the manufacturer.

Wound healing assay. MDA-MB-231 cells and MCF-7 cells were seeded $\left(2 \times 10^{5}\right.$ cells/well) into 6 -well plates and cultured for $48 \mathrm{~h}$ at $37^{\circ} \mathrm{C}$. Once the cells reached a confluence of $90 \%$, a $200 \mu \mathrm{l}$ plastic tip was used to make a straight line in the monolayer, and the plate was washed with PBS. Fresh serum-free medium with vehicle or different concentrations of BBM $(10,20$ and $40 \mu \mathrm{M})$ and mitomycin $(2 \mu \mathrm{g} / \mathrm{ml})$ was added into each well. The cells were observed under an inverted microscope coupled to a camera (100x, Leica DMI 4000) at $25^{\circ} \mathrm{C}$, and this time was designated at $0 \mathrm{~h}$, then the cells were placed in an incubator with $5 \% \mathrm{CO}_{2}$ for $24 \mathrm{~h}$ (MDA-MB-231 cells) or
$72 \mathrm{~h}$ (MCF-7 cells) at $37^{\circ} \mathrm{C}$. The cells were observed under an inverted microscope coupled to a camera $(100 \mathrm{x}$, Leica DMI $4000)$ at $25^{\circ} \mathrm{C}$. The migration distance was measured using Image J (National Institutes of Health, USA, v 1.5.1), and the migration percentage was calculated, the percentage of wound closure $=($ the scratch area of $0 \mathrm{~h}$-the scratch area of $24 \mathrm{~h}) /$ the scratch area of $0 \mathrm{~h}$.

Transwell assay. MDA-MB-231 cells and MCF-7 cells $\left(8 \times 10^{4}\right.$ cells) in the presence or absence of different concentrations of $\operatorname{BBM}(10,20$ and $40 \mu \mathrm{M})$ were suspended in serum-free medium and then seeded into the upper chamber of a transwell chamber with an $8-\mu \mathrm{m}$ pore (Corning, Inc.). The upper chambers were pre-coated at $37^{\circ} \mathrm{C}$ with (Transwell invasion assay) or without (Transwell migration assay) Matrigel $(1 \mathrm{mg} / \mathrm{ml}$ ), and the lower chambers contained medium with $20 \%$ FBS. The chambers were incubated for $36 \mathrm{~h}$ (MDA-MB-231) or $48 \mathrm{~h}$ (MCF-7) at $37^{\circ} \mathrm{C}$. The cells on the surface of the membrane were fixed with $4 \%$ polyoxymethylene at $25^{\circ} \mathrm{C}$ for $30 \mathrm{~min}$ and stained with crystal violet staining solution $(1 \%)$ at $25^{\circ} \mathrm{C}$ for $5 \mathrm{~min}$. Mitomycin $(2 \mu \mathrm{g} / \mathrm{ml})$ was added when the cells were seeded into the upper chambers to exclude the proliferation of the cells. Cells visualized under a light microscope (Leica DM 4000; magnification, x100).

Western blotting assay. Cells were lysed using RIPA lysis buffer. Protein concentration was determined using a BCA assay kit (Beyotime Institute of Biotechnology; cat. no. P0012). Lysate proteins $(20 \mu \mathrm{g})$ were then separated 
A

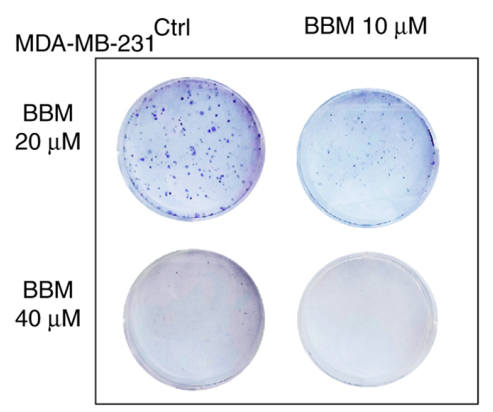

B

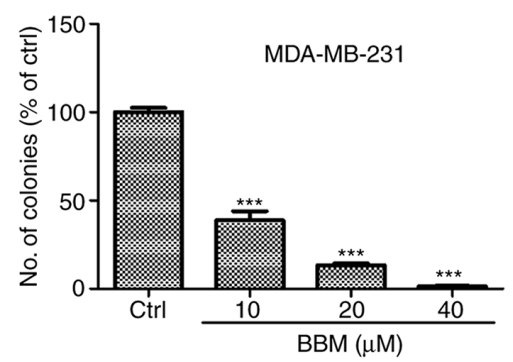

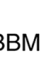
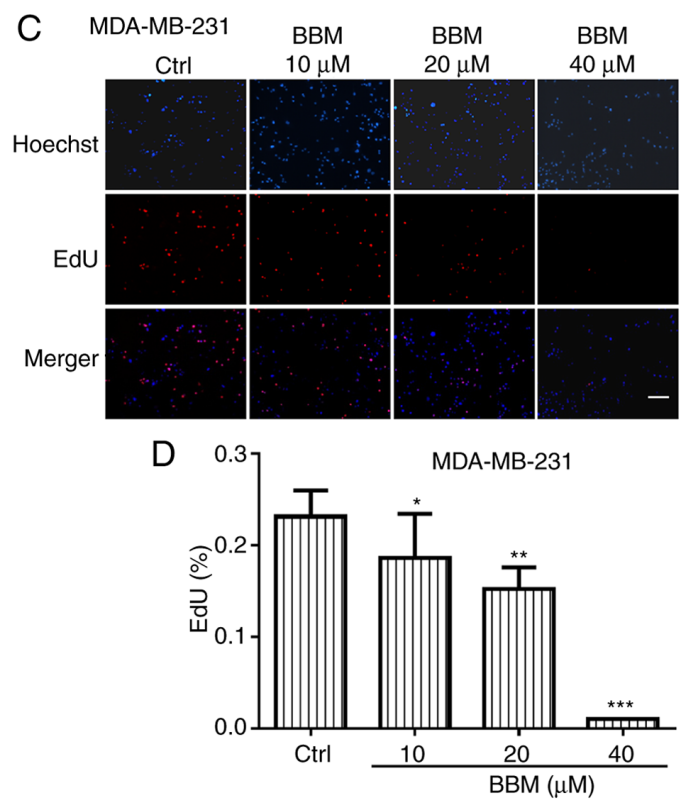
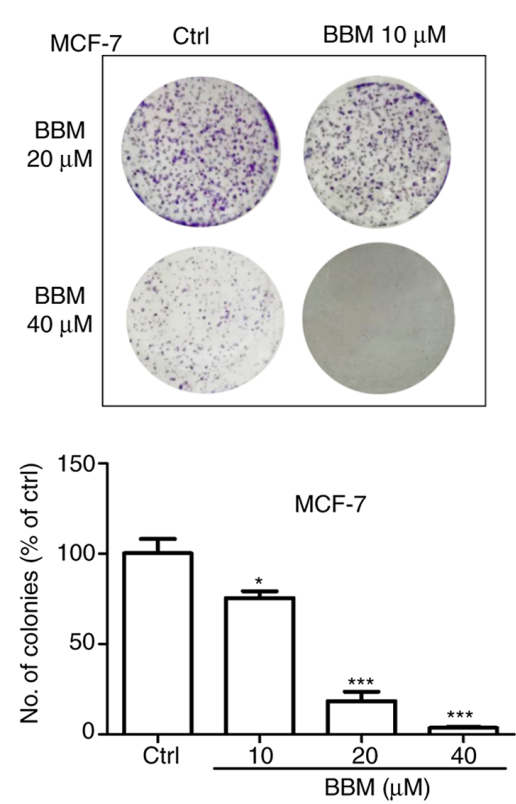

MCF-7

BBM
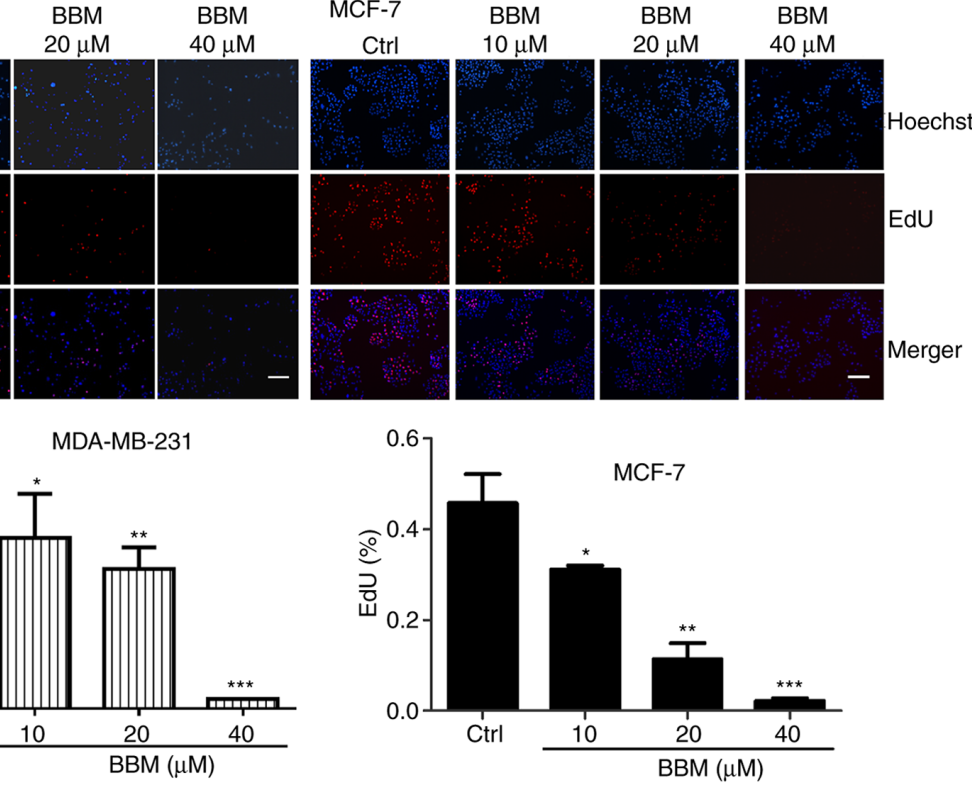

Figure 2. BBM inhibits the proliferation of triple negative breast cancer cells. Cells were treated with applied concentrations (10, 20 and $40 \mu \mathrm{M})$ of $\mathrm{BBM}$ (A) The cell proliferation was tested using a colony formation assay and medium was renewed every 3 days. (B) Quantification of colony forming assay results. (C) EdU assay images and (D) quantification (scale bar, $100 \mu \mathrm{m}$ ). The Ctrl group was untreated cells. Data are presented as the mean \pm standard deviation ( $=3$ ). ${ }^{*} \mathrm{P}<0.05,{ }^{* *} \mathrm{P}<0.01,{ }^{* * *} \mathrm{P}<0.001$ vs. Ctrl group. BBM, Berbamine; Ctrl, control.

by $10 \%$ SDS-PAGE and transferred to a PVDF membrane (EMD Millipore). The membranes were blocked using TBST (containing tween 20,0.05\%) containing 5\% non-fat milk at room temperature for $2 \mathrm{~h}$ and then incubated with primary antibodies against PI3K (cat. no. ab70912; 1:1,000), MDM2 (cat. no. ab16895; 1:500), Akt (cat. no. ab8805; 1:1,000), p-Akt (cat. no. ab38449; 1:1,000) COX-2 (cat. no. sc-19999; 1:200), LOX (cat. no. sc-373995; 1:500), GAPDH (Abcam; cat. no. ab9845; $1: 1,000)$ and $\beta$-actin (cat. no. sc-8432; $1: 1,000)$ at $4^{\circ} \mathrm{C}$ overnight. After washing with TBST, the membranes were incubated with secondary antibodies (GenScript; cat. no. A00098; 1:10,000) conjugated to horseradish peroxidase at room temperature for $2 \mathrm{~h}$. Bands were detected using THE Hypersensitive ECL chemiluminescence kit (Beyotime Institute of Biotechnology; cat. no. P10018FS). Optical density of bands (relative to GAPDH or $\beta$-actin) were quantified using Image $\mathrm{J}$ (National Institutes of Health; v1.5.1).

ELISA. mTOR (pSer2448) level was assayed using the mTOR ELISA kit (Abcam, cat. no. ab176657). Cells were lysed in RIPA buffer as described above and mTOR was detected according to the manufacturer's instructions.

Statistical analysis. All statistical analyses were performed using SPSS 21.0 (IBM Corp.). Data are presented as mean \pm standard deviation (SD). Significance differences were determined using one-way ANOVA, followed by Dunnett's post hoc test. $\mathrm{P}<0.05$ was considered to indicate a statistically significant difference. 
A MDA-MB-231
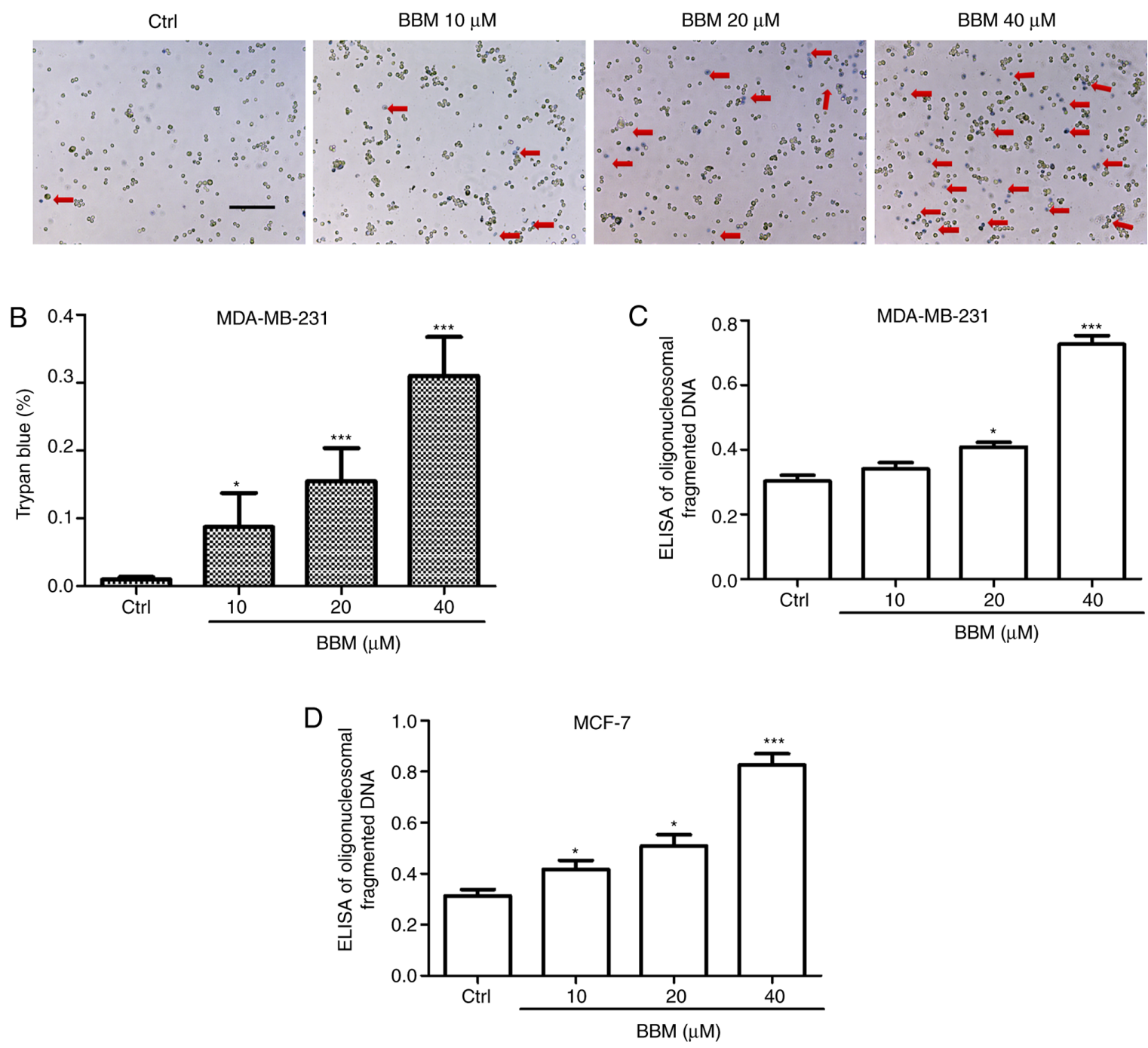

Figure 3. BBM induces triple negative breast cancer cell death. Cells were untreated (Ctrl) or treated with BBM (10,20 and $40 \mu \mathrm{M})$. Cell death and apoptosis were (A) detected using a Trypan blue dye assay (scale bar, $100 \mu \mathrm{m}$, the arrows indicated that the cells were stained with Trypan blue) and (B) quantified. Cell Death Detection ELISA assays in (C) MCF-7 and (D) MDA-MB-231 cells. The Ctrl group was untreated cells. Data are presented as the mean \pm standard deviation $(\mathrm{n}=3) .{ }^{*} \mathrm{P}<0.05,{ }^{* * *} \mathrm{P}<0.001$ vs. Ctrl group. BBM, Berbamine; Ctrl, control.

\section{Results}

$B B M$ inhibits the cell viabilities of MDA-MB-231 and MCF-7 cells. MTT assay was used to detect the effects of BBM on the proliferation of human TNBC cell lines. The results demonstrated that BBM significantly inhibited the cell viabilities of MDA-MB-231 cells and MCF-7 cells in a time- and dose-dependent manner; Fig. 1A). In MDA-MB-231 cells, after incubation for 24,48 , and $72 \mathrm{~h}$, the minimum concentration of BBM inhibited cell proliferation was $10 \mu \mathrm{M}$. Moreover, with the extension of incubation time, the proliferation rate of cells inhibited by BBM was significantly decreased at the same concentration. In MCF-7 cells, the minimum concentration of BBM inhibited cell proliferation was $20 \mu \mathrm{M}$ for $24 \mathrm{~h}$ treated cells, $10 \mu \mathrm{M}$ for $48 \mathrm{~h}$, and $2.5 \mu \mathrm{M}$ for $72 \mathrm{~h}$. In addition, with the extension of incubation time, the proliferation rate of cells inhibited by BBM was significantly decreased as well. The $\mathrm{IC}_{50}$ values of BBM for $72 \mathrm{~h}$ on MDA-MB-231 cells and MCF-7 cells were $22.7 \pm 3.3$, and $20.9 \pm 1.5 \mu \mathrm{M}$, respectively (Fig. 1B).
IC50 value of $72 \mathrm{~h}$ was selected as the basis to exclude the effect of cell proliferation. Thus, BBM of 10, 20 and $40 \mu \mathrm{M}$ were selected for the subsequent assays.

$B B M$ inhibits the proliferation of $M D A-M B-231$ and $M C F-7$ cells. The effects of BBM on cell proliferation were evaluated using colony formation and EdU staining assays. In MDA-MB-231 cells, compared with the Ctrl group, BBM at 10,20 and $40 \mu \mathrm{M}$ decreased the number of the colonies in a dose-dependent manner ( $\mathrm{P}<0.001$; Fig. $2 \mathrm{~A}$ and $\mathrm{B})$. In MCF-7 cells, BBM at 10, 20 and $40 \mu \mathrm{M}$ decreased the number of the colonies in a dose-dependent manner as well $(\mathrm{P}<0.05, \mathrm{P}<0.001$ and $\mathrm{P}<0.001$, respectively (Fig. $2 \mathrm{~A}$ and $\mathrm{B}$ ). To further elucidate the effect of BMM on the cell proliferation of TNBC cells, EdU staining assay was performed. The results indicated that BBM inhibited cell proliferation in a concentration-dependent manner (Fig. 2C and D). In MDA-MB-231 cells, BBM at 10,20 and $40 \mu \mathrm{M}$ significantly inhibited cell proliferation compared with the $\mathrm{C}$ trl group $(\mathrm{P}<0.05, \mathrm{P}<0.01$ and $\mathrm{P}<0.001$, 
A

MDA-MB-231
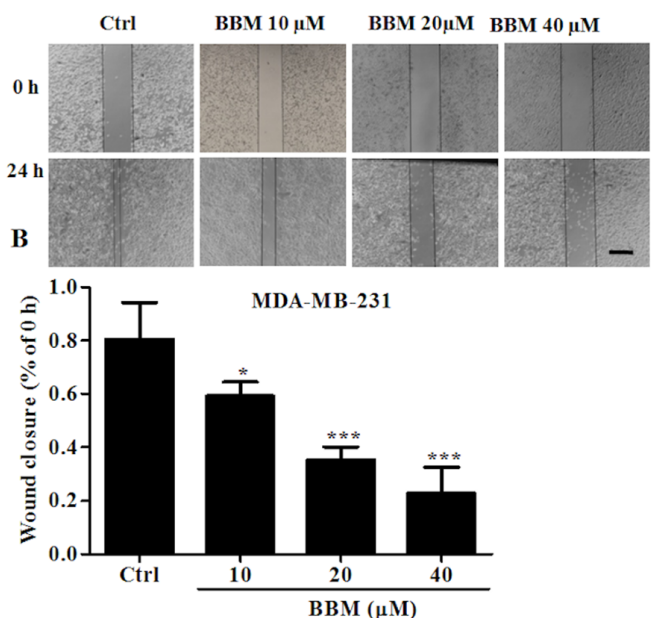

MDA-MB-231
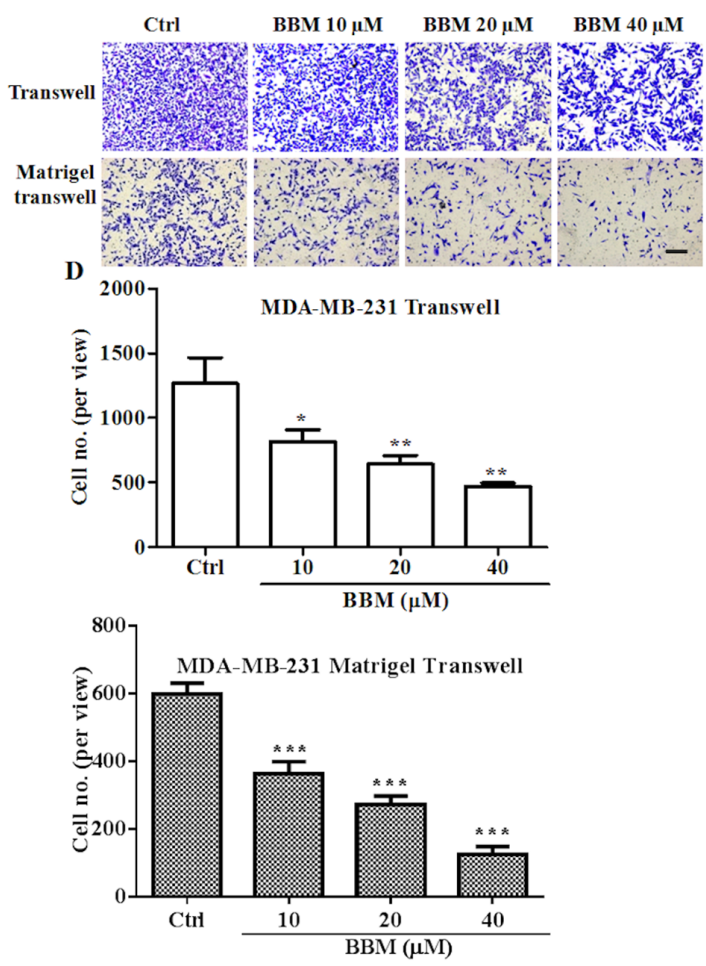

MCF-7
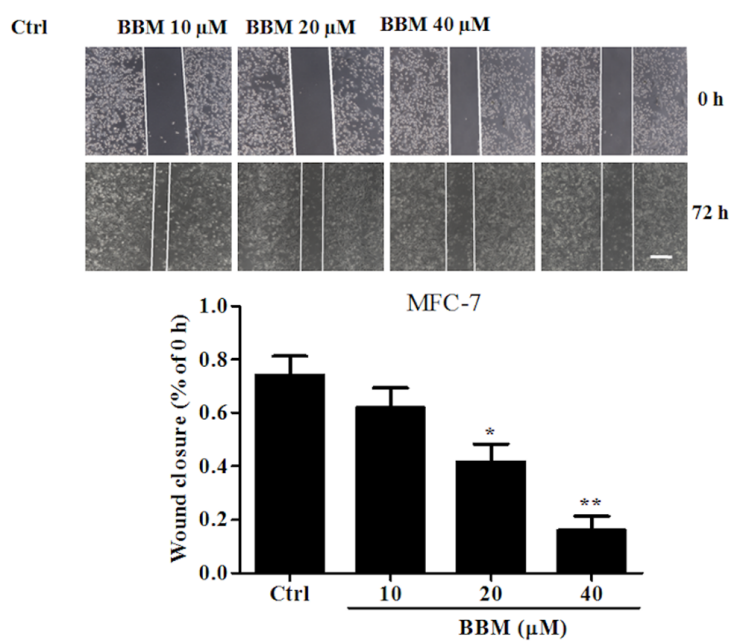

MCF-7
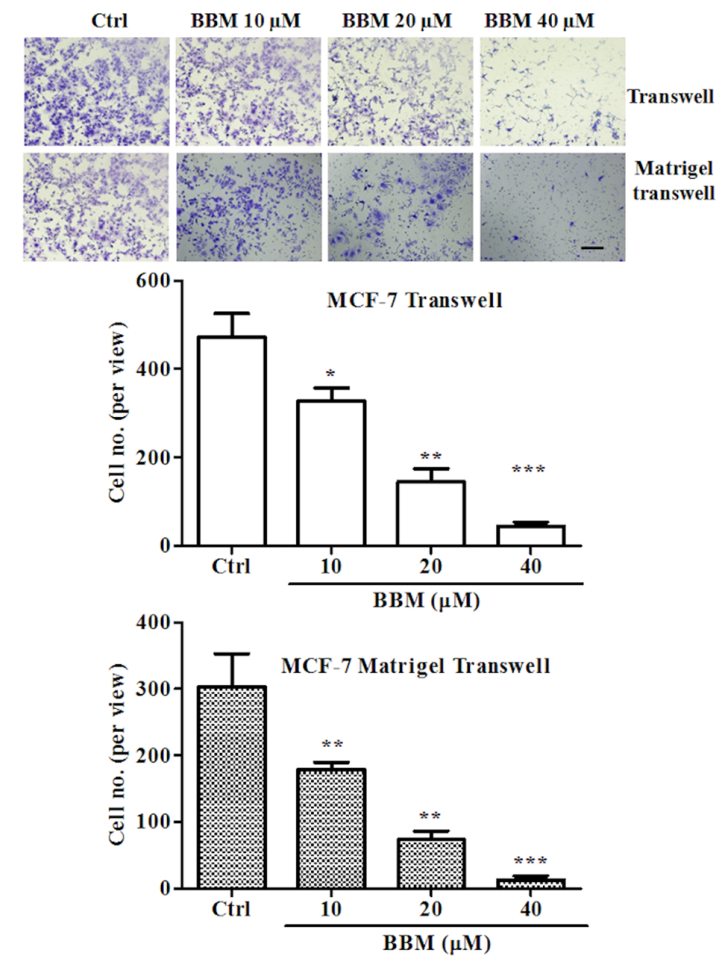

Figure 4. BBM inhibits the migration and invasion of triple negative breast cancer cells. Cells were treated with $\mathrm{BBM}(10,20$ and $40 \mu \mathrm{M})$, migration and invasion were tested using (A) wound closure assays (scale bar, $100 \mu \mathrm{m}$ ) and (B) quantified. (C) Transwell and Matrigel transwell assay cell images (scale bar, $100 \mu \mathrm{m})$ and (D) quantification of the results. The Ctrl group was untreated cells. Data are presented as the mean \pm standard deviation $(\mathrm{n}=3) .{ }^{*} \mathrm{P}<0.05,{ }^{* *} \mathrm{P}<0.01$, **** $\mathrm{P}<0.001$ vs. Ctrl group. BBM, Berbamine; Ctrl, control.

respectively). In MCF-7 cells, BBM at 10, 20, and $40 \mu \mathrm{M}$ significantly inhibited cell proliferation compared with the Ctrl group $(\mathrm{P}<0.05, \mathrm{P}<0.01$ and $\mathrm{P}<0.001$, respectively).

BBM induces apoptosis of MDA-MB-231 and MCF-7 cells. To investigate the effects of BBM on TNBC cell apoptosis, trypan blue and Cell Death Detection ELISA assays were performed. The results showed that BBM induced cell death in a concentration-dependent manner. BBM at 10, 20, and $40 \mu \mathrm{M}$ significantly induced cell death compared to the Ctrl group $(\mathrm{P}<0.05, \mathrm{P}<0.001$ and $\mathrm{P}<0.001$, respectively; Fig. $3 \mathrm{~A}$ and $\mathrm{B})$. In addition, the ELISA assay revealed that BBM at 20 and $40 \mu \mathrm{M}$ significantly induced death of MDA-MB-231 cells compared with the $C$ trl group $(\mathrm{P}<0.05$ and $\mathrm{P}<0.001$, respectively; Fig. 3C). Moreover, BBM at 10, 20, and $40 \mu \mathrm{M}$ induced the cell death of MCF-7 cells compared with the Ctrl group (Fig. 3D) $(\mathrm{P}<0.05, \mathrm{P}<0.05$ and $\mathrm{P}<0.001$, respectively).

$B B M$ inhibits cell migration and invasion in $M D A-M B-231$ and $M C F-7$ cells. Wound healing and transwell assays were performed to evaluate the effects of BBM on cell migration and invasion. The results showed that BBM inhibited wound 
A

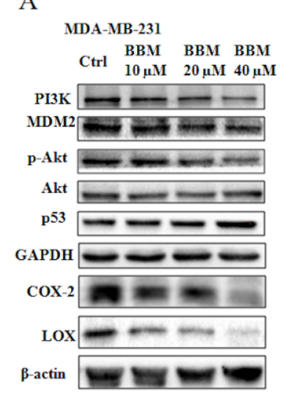

C

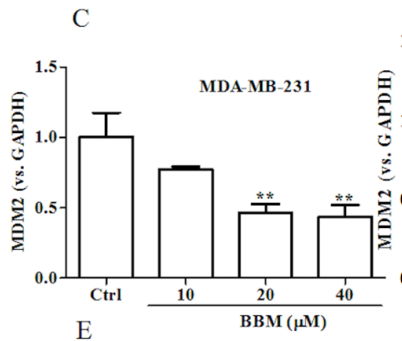

E

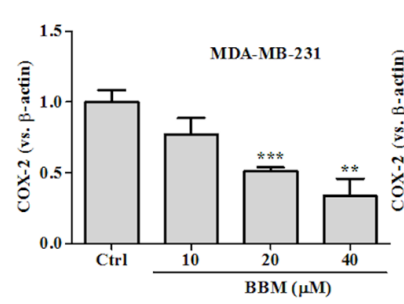

G

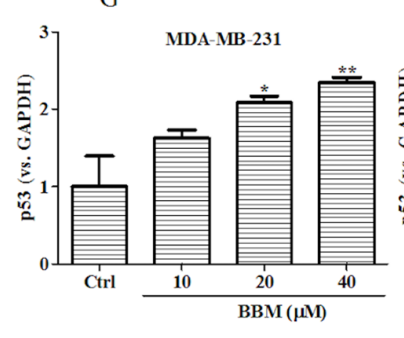

MCF-7

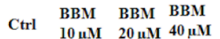

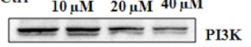

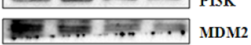

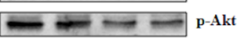

- -

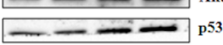

$-\ldots-{ }_{\mathrm{GAPH}}$

$\Longrightarrow \ldots \operatorname{cox}^{2}$

LOx

- - B-actin
B
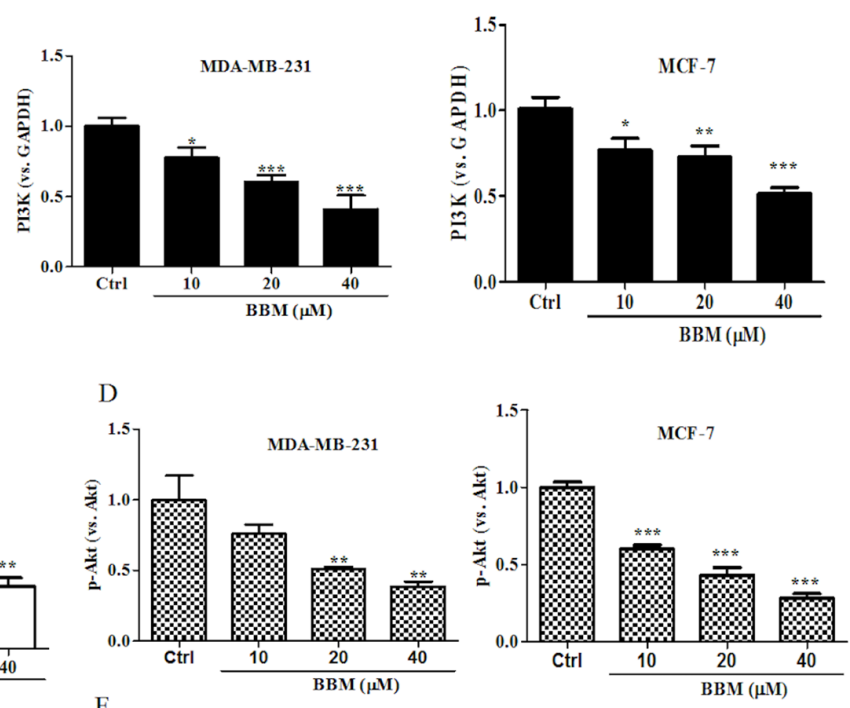

MCF-7
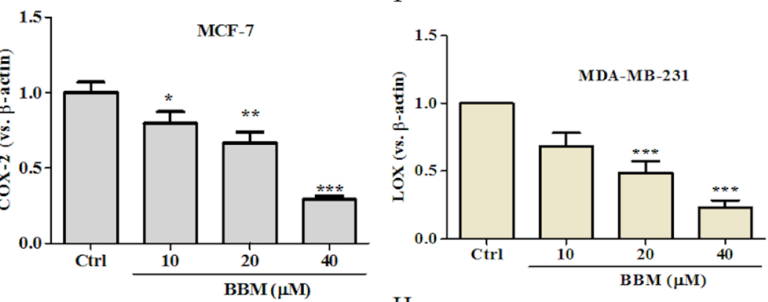

$\mathrm{H}$

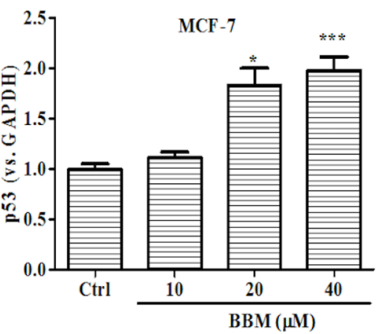

$\mathrm{H}$

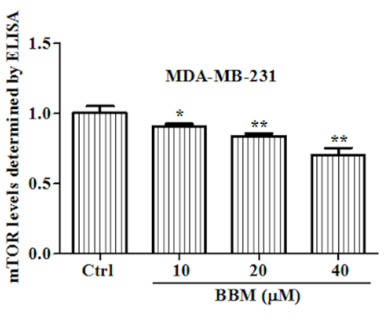

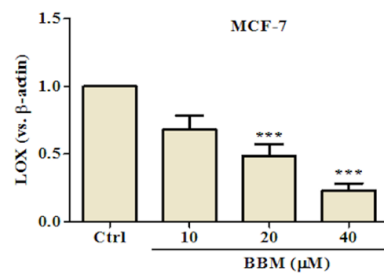

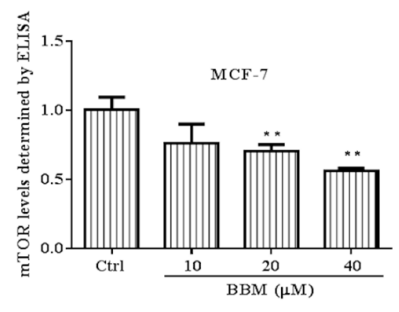

Figure 5. BBM disrupts the PI3K/Akt/MDM2/p53 and PI3K/Akt/mTOR signaling pathways in triple negative breast cancer cells. Cells were untreated (Ctrl) or treated with BBM $(10,20$ and $40 \mu \mathrm{M})$. (A) Western blots were performed on both cell lines. The expression levels of (B) PI3K, (C) MDM2, (D) p-Akt/Akt, (E) COX-2, (F) LOX and (G) p53 were quantified. (H) The expression of p-mTOR was tested using an ELISA. The Ctrl group was untreated cells. Data are presented as the mean \pm standard deviation $(\mathrm{n}=3) .{ }^{*} \mathrm{P}<0.05,{ }^{* *} \mathrm{P}<0.01,{ }^{* * *} \mathrm{P}<0.001$ vs. Ctrl group. BBM, Berbamine; Ctrl, control; $\mathrm{p}-$, phosphorylated-.

closure in a concentration-dependent manner (Fig. 4A and B). $\mathrm{BBM}$ at 10,20 , and $40 \mu \mathrm{M}$ significantly inhibited the migration of MDA-MB-231 cells compared to the Ctrl group $(\mathrm{P}<0.05$, $\mathrm{P}<0.001$ and $\mathrm{P}<0.001$, respectively). $\mathrm{BBM}$ at 20 , and $40 \mu \mathrm{M}$ significantly inhibited the migration of MCF-7 cells compared to the $\mathrm{Ctrl}$ group $(\mathrm{P}<0.05$ and $\mathrm{P}<0.01$, respectively).

It was also revealed that BBM significantly inhibited cell migration and invasion of TNBC cells in a concentration-dependent manner (Fig. 4C and D). In MDA-MB-231 cells, BBM at 20 , and $40 \mu \mathrm{M}$ significantly reduced the number of the migrated cells compared to the Ctrl group $(\mathrm{P}<0.05, \mathrm{P}<0.01$ and $\mathrm{P}<0.01$, respectively). Furthermore, $\mathrm{BBM}$ at 20 , and $40 \mu \mathrm{M}$ significantly reduced the number of invaded cells compared to the $\mathrm{Ctrl}$ group (all $\mathrm{P}<0.001$ ). In MCF-7 cells, $\mathrm{BBM}$ at 20 , and $40 \mu \mathrm{M}$ significantly reduced the number of migrated cells compared to the $\mathrm{Ctrl}$ group $(\mathrm{P}<0.05, \mathrm{P}<0.01$ and $\mathrm{P}<0.001$, respectively). $\mathrm{BBM}$ at 10,20 , and $40 \mu \mathrm{M}$ significantly reduced the number of invaded cells compared to the Ctrl group $(\mathrm{P}<0.01, \mathrm{P}<0.01$ and $\mathrm{P}<0.001$, respectively). These results indicated that $\mathrm{BBM}$ inhibited the cell migration and invasion in TNBC cells.

BBM regulates the PI3K/Akt/MDM2/p53 and PI3K/Akt/mTOR signaling pathways in MDA-MB-231 and MCF-7 cells. The present results revealed that BBM exhibited strong inhibitory effects on cell growth, proliferation, metastasis and invasion in TNBC cells. It was speculated that BBM may serve an anti-cancer role in breast cells via regulation of the PI3K/Akt/MDM2/p53 and PI3K/Akt/mTOR signaling pathways. To verify this hypothesis, the expression levels of PI3K, p-Akt/Akt, MDM2 and p53 were evaluated using western blotting. BBM at 10,20 and $40 \mu \mathrm{M}$ significantly inhibited the expression of PI3K (Fig. 5A and B) both in MDA-MB-231 cells $(\mathrm{P}<0.05)$ and in MCF-7 cells $(\mathrm{P}<0.05)$. $\mathrm{BBM}$ at 20 and $40 \mu \mathrm{M}$ significantly inhibited the expression of MDM2 (Fig. 5A and C) both in MDA-MB-231 cells $(\mathrm{P}<0.01)$ and in MCF-7 cells $(\mathrm{P}<0.05)$. BBM significantly inhibited the expression levels of p-Akt/Akt in MDA-MB-231 cells at 
the concentrations of 20 and $40 \mu \mathrm{M}(\mathrm{P}<0.01)$ and in MCF-7 cells at the concentration of 10,20 and $40 \mu \mathrm{M}(\mathrm{P}<0.001)$ (Fig. 5A and D). BBM significantly inhibited the expression of COX-2 in MDA-MB-231 cells at the concentrations of 20 and $40 \mu \mathrm{M}(\mathrm{P}<0.001)$ and in MCF-7 cells at the concentration of 10,20 and $40 \mu \mathrm{M}(\mathrm{P}<0.001)$ (Fig. $5 \mathrm{~A}$ and $\mathrm{E})$. BBM at 20 and $40 \mu \mathrm{M}$ significantly inhibited the expression of LOX both in MDA-MB-231 cells $(\mathrm{P}<0.001)$ and MCF-7 cells $(\mathrm{P}<0.001)$ (Fig. 5A and F). Notably, BBM at 20 and $40 \mu \mathrm{M}$ increased the expression p53 in MDA-MB-231 $(\mathrm{P}<0.05)$ cells in MCF-7 cells $(\mathrm{P}<0.05)$ (Fig. 5A and $\mathrm{G})$. The expression level of mTOR was tested by ELISA. BBM significantly inhibited the expression of mTOR in MDA-MB-231 cells at of the doses of $10 \mu \mathrm{M}(\mathrm{P}<0.05), 20 \mu \mathrm{M}(\mathrm{P}<0.01)$ and $40 \mu \mathrm{M}$ $(\mathrm{P}<0.01)$ and in MCF-7 cells at the dose of $20 \mu \mathrm{M}(\mathrm{P}<0.01)$ and $40 \mu \mathrm{M}(\mathrm{P}<0.01)$ (Fig. 5H). In summary, the results of the western blot assay indicated that the expression levels of PI3K, MDM2, p-Akt/Akt, COX-2, LOX and mTOR were significantly downregulated by BBM, while the expression of $\mathrm{p} 53$ was upregulated by BBM.

\section{Discussion}

TNBC is the most aggressive subtype of breast cancer and accounts for 15 20\% of all breast cancers worldwide (34). Metastasis is the primary cause of mortality in patients with breast cancer (35). BBM is a traditional medicine derived from Berberis amurensis. Previous studies have demonstrated the anti-tumor effects of BBM in a variety of cancers $(36,37)$. Jin and $\mathrm{Wu}$ (38) demonstrated that BBM significantly downregulates the expressions of apoptosis-related proteins including Bcl-2 and $\mathrm{Bcl}-\mathrm{xL}$ and inhibits cell proliferation in pancreatic carcinoma. Du et al (30) found that BBM induces cell apoptosis and inhibits cell proliferation via the PI3K/Akt pathway in lymphoma. In addition, BBM inhibits cell proliferation and destroys mitochondria in prostate cancer cells (39). These studies support the potential of BBM as a drug for cancer treatment.

In the present study, the effect of BBM on the proliferation, apoptosis, invasion and migration of TNBC cells was evaluated. The present study indicated that the cell proliferation of MAD-MB-231cells and MCF cells was inhibited by BBM. Moreover, BBM induces the apoptosis of TNBC cells. Subsequent experiments revealed that BBM inhibits the invasion and metastasis of TNBC cells. These results are consistent with previous studies $(8,12,17)$ showing that BBM has inhibitory effects on tumors. Western blot was used to detect the effect of BBM on protein expression in TNBC cells to elucidate the possible mechanism of BBM inhibition of proliferation, invasion and metastasis of TNBC cells.

The PI3K/Akt pathway is involved in cell proliferation, apoptosis invasion, and migration, and aberrant activation of this pathway is associated with the development of many types of cancers, breast cancer and lung cancer (40). The present results revealed that cell proliferation, invasion and migration of TNBC cells were inhibited by BBM, and apoptosis was induced by BBM. In addition, the expressions of PI3K and p-Akt/Akt were downregulated following BBM treatment. These results, combined with previous studies, indicate that $\mathrm{BBM}$ may serve an anti-tumor role in TNBC by inhibiting the
PI3K/Akt signaling pathway. Several studies have reported that proteins downstream of Akt regulate cancer cell apoptosis and other cellular events (41-43). For instance, MDM2 is downstream of Akt and inhibits the expression of p53. Overexpression of MDM2 may induce breast cancer via the activation of other oncogenes, such as by promoting ubiquitination/degradation of E-cadherin, resulting in increased invasion of cancer cells (44).

COX-2 is overexpressed in TNBC (28) and may increase the phosphorylation of MDM2, resulting in impaired p53 function (45). Zhang et al (27) reported that COX-2 promotes angiogenesis and tissue invasion in osteosarcoma. The current results revealed that the invasion of TNBC cells was inhibited by BBM. And the expressions of MDM2 and COX-2 were downregulated by BBM treatment, while the expression of $\mathrm{p} 53$ was upregulated. Combined with the aforementioned studies, these findings suggest that BBM inhibits the invasion of TNBC cells via regulating the MDM2-p53 pathway, and the pathway may also be regulated by COX-2. In addition, overexpression of Akt2 induces cell metastasis and invasion via upregulation of integrin $\beta 1$ in breast and ovarian cancers $(3,4)$. mTOR is an important effector of the PI3K/Akt signaling pathway and is expressed in most mammalian cells, resulting in a rise of cellular protein mass and inhibition of autophagy (8). Gao et al (46) found that cepharanthine can induce apoptosis and autophagy by inhibiting the Akt/mTOR signaling pathway (46). Cepharanthine is a natural product and used for $>70$ years in Japan to treat a variety of diseases, including leukopenia (42). These characteristics of cepharanthine are very similar to BBM (47). Moreover, cepharanthine was reported to inhibit the metastasis and invasion, and induce apoptosis of breast cancer cells $(46,48)$. Therefore, we hypothesized that BBM also served an anti-tumor role via the Akt/ mTOR signaling pathway. Furthermore, LOX is high expressed in patients with TNBC, a previous study revealed that LOX promotes cell proliferation and inhibits apoptotic cell death, and this effect may be achieved by activation of the Akt/mTOR signaling pathway (49). The present results indicate that BBM induced the apoptosis of TNBC cells, and the expressions of mTOR and LOX were downregulated following treatment with BBM. Collectively, the current results suggest that BBM may induce the apoptosis of TNBC cells by inhibiting the expressions of mTOR and LOX. MDM2 and mTOR are downstream targets of the PI3K/Akt signaling pathway $(4,21,50,51)$. Thus, it was hypothesized that BBM may induce the apoptosis of TNBC cells via the PI3K/Akt/MDM2/p53 and PI3K/Akt/mTOR signal pathways.

In conclusion, the proliferation, migration and invasion of TNBC cells were suppressed following treatment with BBM, and this effect may be achieved by modulating the PI3K/Akt/MDM2/p53 and PI3K/Akt/mTOR signaling pathways. However, this study is only a preliminary in vitro study, future studies such as in vivo experiments may need to be performed to verify that BBM has low toxicity, and either alone or in combination with other chemotherapy may represent a novel treatment strategy for breast cancer.

\section{Acknowledgements}

Not applicable. 


\section{Funding}

The present work was supported by grants including 'Clinical Medical Science and Technology Development Fund Project' from Jiangsu University (grant no. JLY2016118), The Integrated Traditional Chinese and Western Medicine Research Fund from Suzhou (grant no. SYSD2016173), the Science and Technology Project from Zhangjiagang (grant no. ZKS1638), and the science and technology development plan from Suzhou (grant no. SYSD2019165).

\section{Availability of data and materials}

All data generated or analyzed during the present study are included in this published article.

\section{Authors' contributions}

JY and LL designed the present study, analyzed the data, drafted the initial manuscript and revised it for important intellectual content. YC and YY performed the experiments. BY, LT, XS and LL were responsible for acquiring, analyzing and interpretating the data. SW designed the present study and revised the manuscript for important intellectual content. All authors have read and approved the final manuscript.

\section{Ethics approval and consent to participate}

Not applicable.

\section{Patient consent for publication}

Not applicable.

\section{Competing interests}

The authors declare that they have no competing interest.

\section{References}

1. Guo Y and Pei X: Tetrandrine-induced autophagy in MDA-MB-231 Triple-negative breast cancer cell through the Inhibition of PI3K/AKT/mTOR signaling. Evid Based Complement Alternat Med 20: 7517431, 2019.

2. Jin F, Wu Z, Hu X, Zhang J, Gao Z, Han X, Qin J, Li C and Wang Y: The PI3K/Akt/GSK-3 $\beta /$ ROS/eIF2B pathway promotes breast cancer growth and metastasis via suppression of NK cell cytotoxicity and tumor cell susceptibility. Cancer Biol Med 16: 38-54, 2019

3. Nassan MA, Soliman MM, Ismail SA and El-Shazly S: Effect of Taraxacum officinale extract on PI3K/Akt pathway in DMBA-induced breast cancer in albino rats. Biosci Rep 38: BSR20180334, 2018.

4. Pascual $\mathrm{J}$ and Turner NC: Targeting the PI3-kinase pathway in triple-negative breast cancer. Ann Oncol 30: 1051-1060, 2019.

5. Jouali F, Marchoudi N, Talbi S, Bilal B, El Khasmi M, Rhaissi H and Fekkak J: Detection of PIK3/AKT pathway in Moroccan population with triple negative breast cancer. BMC Cancer 18: 900, 2018.

6. Zhou T, Xu D, Tang B, Ren Y, Han Y, Liang G, Wang J and Wang L: Expression of programmed death ligand-1 and programmed death-1 in samples of invasive ductal carcinoma of the breast and its correlation with prognosis. Anticancer Drugs 29: 904-910, 2018.

7. Sarveazad A, Babahajian A, shamsadin J and Bahardoust M: 5 -year survival rates and prognostic factors in patients with synchronus and metachronus breast cancer from 2010 to 2015. Asian Pac J Cancer Prev 19: 3489-3493, 2018.
8. Fu R, Deng Q, Zhang H, Hu X, Li Y, Liu Y, Hu J, Luo Q, Zhang Y, Jiang $\mathrm{X}$, et al: A novel autophagy inhibitor berbamine blocks SNARE-mediated autophagosome-lysosome fusion through upregulation of BNIP3. Cell Death Dis 9: 243, 2018.

9. Simonetti RG, Camma C, Fiorello F, Politi F, D'Amico G and Pagliaro L: Hepatocellular carcinoma. A worldwide problem and the major risk factors. Dig Dis Sci 36: 962-972, 1991.

10. Li H, Wang Z, Jiang M, Fang RP, Shi H, Shen Y, Cai XL, Liu Q, Ye K, Fan SJ, et al: The oncoprotein HBXIP promotes human breast cancer growth through down-regulating p53 via miR-18b/MDM2 and pAKT/MDM2 pathways. Acta Pharmacol Sin 39: 1787-1796, 2018.

11. Zhu YJ, Zheng B, Wang HY and Chen L: New knowledge of the mechanisms of sorafenib resistance in liver cancer. Acta Pharmacol Sin 38: 614-622, 2017.

12. Zhu H, Ruan S, Jia F, Chu J, Zhu Y, Huang Y and Liu G: In vitro and in vivo superior radiosensitizing effect of berbamine for head and neck squamous cell carcinoma. Onco Targets Ther 11: 8117-8125, 2018.

13. Leal-Orta E, Ramirez-Ricardo J, Cortes-Reynosa P, Galindo-Hernandez O and Salazar EP: Role of PI3K/Akt on migration and invasion of MCF10A cells treated with extracellular vesicles from MDA-MB-231 cells stimulated with linoleic acid. J Cell Commun Signal 13: 235-244, 2019.

14. Tian L, Cheng F, Wang L, Qin W, Zou K and Chen J: CLE-10 from Carpesium abrotanoides L. Suppresses the Growth of human breast cancer cells (MDA-MB-231) in vitro by inducing apoptosis and pro-death autophagy via the PI3K/Akt/mTOR signaling pathway. Molecules 24: 1091, 2019.

15. Xia E, Zhou X, Bhandari A, Zhang X and Wang O: Synaptopodin-2 plays an important role in the metastasis of breast cancer via PI3K/Akt/mTOR pathway. Cancer Manag Res 10: 1575-1583, 2018.

16. Yan W, Ma X, Zhao X and Zhang S: Baicalein induces apoptosis and autophagy of breast cancer cells via inhibiting PI3K/AKT pathway in vivo and vitro. Drug Des Devel Ther 12: 3961-3972, 2018.

17. Wang S, Liu Q, Zhang Y, Liu K, Yu P, Liu K, Luan J, Duan H, $\mathrm{Lu} \mathrm{Z}$, Wang F, et al: Suppression of growth, migration and invasion of highly-metastatic human breast cancer cells by berbamine and its molecular mechanisms of action. Mol Cancer 8: 81, 2009.

18. Stephen H Hare AJ: mTOR function and therapeutic targeting in breast cancer. Am J Cancer Res 7: 383-404, 2017.

19. Zheng S, Lv P, Su J, Miao K, Xu H and Li M: Overexpression of $\mathrm{CBX} 2$ in breast cancer promotes tumor progression through the PI3K/AKT signaling pathway. Am J Transl Res 11: 1668-1682, 2019.

20. Fan L, Zhang Y, Zhou Q, Liu Y, Gong B, Lü J, Zhu H, Zhu G, $\mathrm{Xu} \mathrm{Y}$ and Huang G: Casticin inhibits breast cancer cell migration and invasion by down-regulation of PI3K/Akt signaling pathway. Biosci Rep 38: BSR20180738, 2018.

21. Pierobon M, Ramos C, Wong S, Hodge KA, Aldrich J, Byron S, Anthony SP, Robert NJ,Northfelt DW, Jahanzeb M, et al: Enrichment of PI3K-AKT-mTOR pathway activation in hepatic metastases from breast cancer. Clin Cancer Res 23: 4919-4928, 2017.

22. Qiang P, Shao Y, Sun YP, Zhang J and Chen LJ: Metformin inhibits proliferation and migration of endometrial cancer cells through regulating PI3K/AKT/MDM2 pathway. Eur Rev Med Pharmacol Sci 23: 1778-1785, 2019.

23. Ghoneum A and Said N: PI3K-AKT-mTOR and NFkB pathways in ovarian cancer: Implications for targeted therapeutics. Cancers (Basel) 11: 949, 2019.

24. Qin JJ, Wang W and Zhang R: Experimental therapy of advanced breast cancer: Targeting NFAT1-MDM2-p53 pathway. Prog Mol Biol Transl Sci 151: 195-216, 2017.

25. Rinaldi L, Sepe M, Delle Donne R, Conte K, Arcella A, Borzacchiello D, Amente S, De Vita F, Porpora M, Garbi C, et al: Mitochondrial AKAP1 supports mTOR pathway and tumor growth. Cell Death Dis 8: e2842, 2017.

26. Yoshikawa Y, Takano O, Kato I, Takahashi Y, Shima F and Kataoka T: Ras inhibitors display an anti-metastatic effect by downregulation of lysyl oxidase through inhibition of the Ras-PI3K-Akt-HIF-1 $\alpha$ pathway. Cancer Lett 410: 82-91, 2017.

27. Zhang X, Qu P, Zhao H, Zhao T and Cao N: COX2 promotes epithelialmesenchymal transition and migration in osteosarcoma MG63 cells via PI3K/AKT/NF- $\kappa$ B signaling. Mol Med Rep 20: 3811-3819, 2019.

28. Chan N, Willis A, Kornhauser N, Ward MM, Lee SB, Nackos E, Seo BR, Chuang E, Cigler T, Moore A, et al: Influencing the tumor microenvironment: A phase II study of copper depletion using tetrathiomolybdate in patients with breast cancer at high risk for recurrence and in preclinical models of lung metastases. Clin Cancer Res 23: 666-676, 2017. 
29. Mosalpuria K, Hall C, Krishnamurthy S, Lodhi A, Hallman DM Baraniuk MS, Bhattacharyya A and Lucci A: Cyclooxygenase-2 expression in non-metastatic triple-negative breast cancer patients. Mol Clin Oncol 2: 845-850, 2014.

30. Du HP, Shen JK, Yang M, Wang YQ, Yuan XQ, Ma QL and Jin J: 4-Chlorobenzoyl berbamine induces apoptosis and G2/M cell cycle arrest through the PI3K/Akt and NF-kappaB signal pathway in lymphoma cells. Oncol Rep 23: 709-716, 2010.

31. Zhang L, Tong J, He X, Liang Y, Zhu L, Xu R and Zhao X: Novel synthetic 4-chlorobenzoyl berbamine inhibits c-Myc expression and induces apoptosis of diffuse large B cell lymphoma cells. Ann Hematol 97: 2353-2362, 2018.

32. Wang SS, Lv Y, Xu XC, Zuo Y, Song Y, Wu GP, Lu PH, Zhang ZQ and Chen MB: Triptonide inhibits human nasopharyngeal carcinoma cell growth via disrupting Lnc-RNA THOR-IGF2BP1 signaling. Cancer Lett 443: 13-24, 2019.

33. Cummins CB, Wang X, Xu J, Hughes BD, Ding Y, Chen H, Zhou J and Radhakrishnan RS: Antifibrosis effect of novel oridonin analog CYD0618 via suppression of the NF- $\kappa$ B pathway. J Surg Res 232: 283-292, 2018.

34. Saatci O, Kaymak A, Raza U, Ersan PG, Akbulut O, Banister CE, Sikirzhytski V, Tokat UM, Aykut G, Ansari SA, et al: Targeting lysyl oxidase (LOX) overcomes chemotherapy resistance in triple negative breast cancer. Nat Commun 11: 2416, 2020.

35. Meng F, Wu L, Dong L, Mitchell AV, James Block C, Liu J, Zhang H, Lu Q, Song WM, Zhang B, et al: EGFL9 promotes breast cancer metastasis by inducing cMET activation and metabolic reprogramming. Nat Commun 10: 5033, 2019.

36. Liu R, Zhang Y, Chen Y, Qi J, Ren S, Xushi MY, Yang C, Zhu $\mathrm{H}$ and Xiong D: A novel calmodulin antagonist O-(4-ethoxyl-butyl)-berbamine overcomes multidrug resistance in drug-resistant MCF-7/ADR breast carcinoma cells. J Pharm Sci 99: 3266-3275, 2010.

37. Cao Y, Cao J, Yu B, Wang S, Liu L, Tao L and Sun W: Berbamine induces SMMC-7721 cell apoptosis via upregulating p53, downregulating survivin expression and activating mitochondria signaling pathway. Exp Ther Med 15: 1894-1901, 2018.

38. Jin $\mathrm{X}$ and $\mathrm{Wu} \mathrm{Y}$ : Berbamine enhances the antineoplastic activity of gemcitabine in pancreatic cancer cells by activating transforming growth factor- $\beta /$ Smad signaling. Anat Rec (Hoboken) 297: 802-809, 2014.

39. Zhao Y, Lv JJ, Chen J, Jin XB, Wang MW, Su ZH, Wang LY and Zhang HY: Berbamine inhibited the growth of prostate cancer cells in vivo and in vitro via triggering intrinsic pathway of apoptosis. Prostate Cancer Prostatic Dis 19: 358-366, 2016.

40. Ding X, Wang Q, Tong L, Si X and Sun Y: Long non-coding RNA FOXO1 inhibits lung cancer cell growth through down-regulating PI3K/AKT signaling pathway. Iran J Basic Med Sci 22: 491-498, 2019.
41. Deng S, Dai G, Chen S, Nie Z, Zhou J, Fang H and Peng H: Dexamethasone induces osteoblast apoptosis through ROS-PI3K/AKT/GSK $3 \beta$ signaling pathway. Biomed Pharmacother 110: 602-608, 2019.

42. Leszczynska KB, Foskolou IP, Abraham AG, Anbalagan S, Tellier C, Haider S, Span PN, O'Neill EE, Buffa FM and Hammond EM: Hypoxia-induced p53 modulates both apoptosis and radiosensitivity via AKT. J Clin Invest 125: 2385-2398, 2015.

43. Yue X, Li M, Chen D, Xu Z and Sun S: UNBS5162 induces growth inhibition and apoptosis via inhibiting PI3K/AKT/mTOR pathway in triple negative breast cancer MDA-MB-231 cells. Exp Ther Med 16: 3921-3928, 2018.

44. Wang W, Wu J, Fei X, Chen W, Li Y, Shen K and Zhu L: CHD1L promotes cell cycle progression and cell motility by up-regulating MDM2 in breast cancer. Am J Transl Res 11: 1581-1592, 2019.

45. Liu XH, Kirschenbaum A, Yu K, Yao S and Levine AC Cyclooxygenase-2 suppresses hypoxia-induced apoptosis via a combination of direct and indirect inhibition of p53 activity in a human prostate cancer cell line. J Biol Chem 280: 3817-3823, 2005.

46. Gao S, Li X, Ding X, Qi W and Yang Q: Cepharanthine induces autophagy, apoptosis and cell cycle arrest in breast cancer cells. Cell Physiol Biochem 41: 1633-1648, 2017.

47. Haginaka J, Kitabatake T, Hirose I, Matsunaga H and Moaddel R: Interaction of cepharanthine with immobilized heat shock protein $90 \alpha(\mathrm{Hsp} 90 \alpha)$ and screening of Hsp90 $\alpha$ inhibitors. Anal Biochem 434: 202-206, 2013.

48. Bailly C: Cepharanthine: An update of its mode of action, pharmacological properties and medical applications. Phytomedicine 62: 152956, 2019.

49. Kim BR, Dong SM, Seo SH, Lee JH, Lee JM, Lee SH and Rho SB: Lysyl oxidase-like 2 (LOXL2) controls tumor-associated cell proliferation through the interaction with MARCKSL1. Cell Signal 26: 1765-1773, 2014.

50. Wang Y, Sun H, Xiao Z, Zhang G, Zhang D, Bao X, Li F, Wu S, Gao Y and Wei N: DNA damage and apoptosis induced by a potent orally podophyllotoxin derivative in breast cancer. Cell Commun Signal 16: 52, 2018.

51. Kanaizumi H, Higashi C, Tanaka Y, Hamada M, Shinzaki W, Azumi T, Hashimoto $\mathrm{Y}$, Inui $\mathrm{H}$, Houjou $\mathrm{T}$ and Komoike $\mathrm{Y}$ : $\mathrm{PI} 3 \mathrm{~K} / \mathrm{Akt} / \mathrm{mTOR}$ signalling pathway activation in patients with ER-positive, metachronous, contralateral breast cancer treated with hormone therapy. Oncol Lett 17: 1962-1968, 2019.

(i) (9) This work is licensed under a Creative Commons Attribution-NonCommercial-NoDerivatives 4.0 International (CC BY-NC-ND 4.0) License. 